\title{
RESEARCH
}

Open Access

\section{Physiological and biochemical role of proline, trehalose, and compost on enhancing salinity tolerance of quinoa plant}

Maha Mohamed-Shater Abdallah', Talaat N. El Sebai², Amany Abd El-Mohsen Ramadan ${ }^{1 *}$ (D) and Hala Mohamed Safwat El-Bassiouny'

\begin{abstract}
Background and objective: Researches on compost introduced the evidence of its benefits to plant productivity and soil fertility. These advantages are noticed in forms of improving soil water holding capacity and nutrient availability for plants. These changes can also improve plants' capability to overcome salinity stress conditions. The application of osmo-protectant materials (proline and trehalose) and/or compost addition enhances plant antioxidative defense system against stress conditions. This experiment conducted to study the effect of spraying quinoa plants with proline and trehalose with and without soil compost addition under salinity stress on some morphological and physiological aspects.

Materials and methods: Quinoa plant was grown with or without compost in the soil and foliar sprayed with proline or trehalose under salt irrigation. Plant samples were taken after 60 days from sowing and at the end of the experiment for growth, yield, and biochemical measurements.

Results: Growth and yield measurements were decreased with salinity stress. High levels of both proline and trehalose recorded the highest values of total soluble sugars, proline, and free amino acids in both unstressed or salinity stressed plants with or without compost addition. The use of compost in soil for cultivating quinoa plants with either proline or trehalose treatments increased growth parameters, photosynthetic pigments, and yield attributes. In addition, these treatments improved the accumulation of some organic solutes in leaves and promoted antioxidant enzyme activities.
\end{abstract}

Conclusion: Compost addition to soil with spraying proline or trehalose improved quinoa growth and yield and produced seed nutritional value.

Keywords: Proline, Trehalose, Growth, Antioxidant enzymes, Minerals, Yield, Quinoa

\footnotetext{
* Correspondence: amanyramadan66@yahoo.com

'Department of Botany, Agricultural and Biological Research Division,

National Research Centre, 33 El Bohouth Street, P.O. Box 12622, Giza, Dokki,

Egypt

Full list of author information is available at the end of the article
}

() The Author(s). 2020 Open Access This article is licensed under a Creative Commons Attribution 4.0 International License, which permits use, sharing, adaptation, distribution and reproduction in any medium or format, as long as you give appropriate credit to the original author(s) and the source, provide a link to the Creative Commons licence, and indicate if changes were made. The images or other third party material in this article are included in the article's Creative Commons licence, unless indicated otherwise in a credit line to the material. If material is not included in the article's Creative Commons licence and your intended use is not permitted by statutory regulation or exceeds the permitted use, you will need to obtain permission directly from the copyright holder. To view a copy of this licence, visit http://creativecommons.org/licenses/by/4.0/. 


\section{Introduction}

A large number of people around the world about 780 million persons are located in the undeveloped regions according to the FAO (2014). From history point of view, Gonzalez et al. (2012) stated that quinoa (Chenopodium quinoa) was cultivated from about 3000 B.C. and it is still cultivated in Peru, Bolivia, Chile, Ecuador, Colombia, and Argentina. Moreover, during the last decade, quinoa played an important role in food security, thus focusing global attention on nutrition and poverty eradication event by the United Nations declaring the year 2013 as its international year (FAO 2013). It has been used as a staple food crop for thousands of years (Martinez et al. 2015). Nowak et al. (2016) mentioned that quinoa is one of humans' foods that have high total antioxidant capacity and used as an excellent source of essential amino acids, micronutrients, vitamins, phenolic compounds, and minerals.

Climatic changes due to global warming cause drought and salinity that seriously reduce yield and crop quality (Ramadan et al. 2020). Consequently, it was necessary to study the physiological response of plants to salt stress in order to develop appropriate plans to produce food under environmental stress conditions (Abdallah et al. 2020). Recently, in Egypt, a large-scale land reclamation is needed for large amounts of water for irrigation for good potent of plant growth and high yield. Thus, the use of various sources of irrigation water became a must, and these sources often have relatively high salinity levels such as well water (Abdallah et al. 2020). Salinity (abiotic stress agent) is one of the most important factors appearing in areas characterized by low amounts of fresh water, high evapotranspiration rate, and lack of precipitation, which has a harmful effect on crop production.

El Sebai et al. (2016) reported that salt stress is considered one of the most important abiotic stresslimiting plant growth and productivity through increases in reactive oxygen species (ROS). These ROS may cause cellular destruction by oxidative stress in the forms of lipids oxidation, proteins, and nucleic acids (Beltagi 2008). The extensive use of mineral fertilizers, low rainfall, high evaporation rate, poor irrigation water, and poor water management induces declining in soil fertility and increasing soil salinization which are considered the main problems faced by farmers all over the world (Rady et al., 2013). Therefore, attention is drawn on using various forms of composts as partial substitutions to mineral fertilizers as sources of nutrients due to high alkalinity and low rains under normal or saline condition (Smith et al. 2015). It is also well known that application of compost has positive effects on the soil characteristics, in addition to its beneficial effects in terms of improved crop productivity, soil fertility and sustainability, and balanced plant nutrition (El Sebai et al. 2016).

Trehalose (a non-reducing disaccharide of glucose consisting of two units of glucose " $\alpha$-D-glucopyranosyl$1,1-\alpha$-D-glucopyranoside") is one of the higher plantsynthesized substances that plays the protectant role (abiotic stress) in plants (Almeida et al. 2007). Jain and Roy (2009) reported that the stress protectant substance (Trehalose) is synthesized when plants are exposed to stress factors, e.g., heat, cold, oxidation, desiccation, and so forth. Also, Fernandez et al. (2010) reported that trehalose is an energy source and has unique physicochemical properties since it efficiently stabilizes dehydrated enzymes, proteins, and lipid membranes. Recently, Sadak et al. (2019) explained the trehalose role in preventing the damage of biological structures during desiccation by acting as molecules of signaling and antioxidant. Application of osmo-protectants as trehalose was found to induce positive effects in plant growth overcoming the adverse effects of salinity stress (Abdallah et al. 2016). They added that such an effect of trehalose as a non-reducing disaccharide of glucose came through inducing stabilizes in biological structures and macromolecules (membrane lipids and proteins) with abiotic stresses.

The foliar spraying of proline is known to tolerate abiotic stress in different plants (Ali et al. 2008). Nanjo et al. (2003) found that the increase in Arabidopsis plant intracellular proline accumulation significantly inhibited other genes responsible for the synthesis of other amino acids or normal morphogenesis. Rontein et al. (2002) reported that proline is involved in cell osmoregulation and protection of proteins during dehydration and can act as an enzymatic regular during stress conditions. Also, it is a dominant organic molecule, under salinity stress, responsible for osmotic adjustment mediation as well as stabilizing sub-cellular structures that could be considered a bowl for energy and a stress-related signal. Ashraf and Foolad (2007) concluded that excessive amount and free proline has negative or side effects on cell growth or on protein functions; accordingly, its effect vigor was correlated to its concentration. They also reported that the effectiveness of foliar-sprayed proline depends on the used concentration, plant species, plant development stage, and time of application.

So, the current experimental work is carried out by spraying quinoa plant with different concentrations of proline and trehalose with or without compost supplementation to the soil irrigated with saline water to study these treatment effects on some growth, physiological, and yield parameters as well as some quality indicators of the yielded seeds. 


\section{Materials and methods}

\section{Plant materials and growth conditions}

Quinoa (Chenopodium quinoa Masr 1) plant in the present experiment was obtained from Agricultural Research Centre, Giza, Egypt, and tested for its sensitivity to salinity stress. The applied substances (proline and trehalose) were supplied from Sigma Chemical Company, St. Louis, MO, USA. The current study was carried out to clarify the roles of both proline and trehalose with or without adding compost to growing soil on growth, some physiological parameters, yield, and chemical composition of the yielded seeds of quinoa under different salinity levels. Quinoa seeds were sown at the end of November in pots during two successive winter seasons (2016/2017 and 2017/2018) in the greenhouse of $\mathrm{Na}$ tional Research Centre, Cairo, Egypt. The salt type and its components used in irrigation were mainly the chloride mixture suggested by Stroganov (1962) as shown in Table 1. The used compost was prepared by El-Sebai et al., (2014) and its physico-chemical properties are presented in Table 2.

Seeds were grown in pots $(50 \mathrm{~cm}$ diameter); each pot filled with equal amounts of homogenous clay and sand $(2: 1)$. Soil characteristics were sandy loam in texture, sand $84.2 \%$, silt $12.9 \%$, clay $2.9 \%, \mathrm{pH} 7.7, \mathrm{EC} 0.5 \mathrm{dSm}^{-1}$, and organic matter $1.2 \%$. After the inoculation of the soil by the recommended amount of compost, seven seeds per pot were used and thinned to four at 2 weeks post planting. Five replicates were used for each treatment after the inoculation of the soil by the recommended amount of compost. The trehalose concentrations $(2.5$ and $5.0 \mathrm{mM})$ compared with two concentrations of proline $(0.5$ and $1.0 \mathrm{mM})$ were sprayed twice after 30 and 45 days of cultivation. The fertilization with super phosphate $(5 \mathrm{~g} /$ pot $)$, potassium sulfate $(25 \mathrm{~g} / \mathrm{pot})$, and urea (6 g/pot) were used (EL-Sebai et al. 2016).

The pots were divided into two main groups; the first group was without compost and the second inoculated with compost. Each group was divided into three subgroups according to irrigation with different levels of saline solutions recommended by Stroganov's (1962) nutrient solutions at the rates of $0.0,3000$, and $6000 \mathrm{mg} /$ $\mathrm{L}$, which is equal to $\mathrm{EC}$ of $0.03,5.0$, and $9.0 \mathrm{dSm}^{-1}$ ), respectively. Each of the previous subgroups was divided

Table 1 Salt mixture components for the used chloride salinization (expressed as percentage of total salt content)

\begin{tabular}{llllc}
\hline $\mathrm{MgSO}_{4}$ & $\mathrm{CaSO}_{4}$ & $\mathrm{NaCl}$ & $\mathrm{MgCl}_{2}$ & $\mathrm{CaCO}_{3}$ \\
\hline 10 & 1 & 78 & 2 & 9
\end{tabular}

Specific anions and cations in chloride mixture (\% of total mill equivalents):

\begin{tabular}{llllll}
$\mathrm{Na}^{+}$ & $\mathrm{Mg}^{+2}$ & $\mathrm{Ca}^{+2}$ & $\mathrm{SO}^{-2}$ & $\mathrm{Cl}^{-}$ & $\mathrm{CO}_{3}^{-2}$ \\
38 & 6 & 6 & 5 & 40 & 5 \\
\hline
\end{tabular}

Table 2 Physico-chemical properties of compost used through this study

\begin{tabular}{lll}
\hline Character & Unit & Value* \\
\hline Bulk density & $\mathrm{kg}$ & 528 \\
Moisture content & $\%$ & 53 \\
$\mathbf{p H}(\mathbf{1 : 1 0})$ & $\mathrm{ds} / \mathrm{m}$ & 7.62 \\
EC (1:10) & $\%$ & 2.96 \\
Total nitrogen & $\mathrm{ppm}$ & 1.07 \\
Ammonium nitrogen $\left(\mathbf{N H}_{\mathbf{4}}-\mathbf{N}\right)$ & $\mathrm{ppm}$ & 114 \\
Nitrate nitrogen $\left(\mathbf{N O}_{\mathbf{3}}-\mathbf{N}\right)$ & $\%$ & 19 \\
Organic matter & $\%$ & 33.47 \\
Organic carbon & $\%$ & 19.41 \\
Ash & & 66.53 \\
C:N ratio & $\%$ & $18.14: 1$ \\
Total phosphorus $\left(\mathbf{P}_{\mathbf{2}} \mathbf{O}_{\mathbf{5}}\right)$ & $\%$ & 0.36 \\
Total potassium $\left(\mathbf{K}_{\mathbf{2}} \mathbf{O}\right)$ & & 2.48 \\
\hline
\end{tabular}

*All analyses were carried out on the basis of dry weight except for moisture content

into four groups and sprayed twice with two proline concentrations ( 0.50 and $1.0 \mathrm{mM})$ and two concentrations of trehalose (2.5 and $5.0 \mathrm{mM})$. Each treatment consisted of 5 replicates distributed in split-split plot in a completely randomized design system. The seedlings were irrigated with an equal volume $(1 \mathrm{~L} / \mathrm{pot})$ of different salt solutions three times, whereas tap water was used for the fourth one to prevent the accumulation of salts around root system. The seedlings were left under the following natural growth conditions: $12 \mathrm{~h}$ light period, $65-70 \%$ relative humidity, and day/night temperatures of $24 / 16^{\circ} \mathrm{C}$. The plant samples were taken after 60 days from sowing for estimation of some growth parameters as well as chemical analysis of photosynthetic pigments. At harvest stage, yield and yield attributes were measured.

\section{Growth trait measurements}

A 60-day-old sample was collected to determine some morphological traits and some chemical constituents. The morphological traits measurements were plant length $(\mathrm{cm})$ and fresh and dry weights of shoot (gm/plant).

\section{Yield trait measurements}

At full maturity stage, yield and its components in terms of plant height $(\mathrm{cm})$, number of branches/plant, shoot weight $(\mathrm{gm})$, and seed weight $(\mathrm{gm}) /$ plant were measured.

\section{Chemical analysis}

Some biochemical aspects were assayed including photosynthetic pigments (chlorophyll a, chlorophyll b, carotenoids, and total pigments) in fresh leaves which were estimated using the method of Lichtenthaler and Buschmann (2001). Total soluble sugars (TSS) were extracted 
according to Homme et al. (1992) and determined according to Yemm and Willis (1954). Proline content was extracted and calculated according to the methodology of Bates et al. (1973). Free amino acids (free AA) were extracted as outlined by Vartainan et al. (1992) and determined with the ninhydrin reagent method reported by Yemm and Cocking (1955). Enzyme extracts were prepared according to the method of Chen and Wang (2006). Catalase (CAT, EC 1.11.1.6) and Super Oxide Dismutase (SOD, EC 1.12.1.1) activity was calculated by nitro-bluetetrazolium reduction method detected by Chen and Wang (2006). Peroxidase (POX, EC 1.11.1.7) activity was evaluated according to the methodology of Kumar and Khan (1982). Ascorbate peroxidase (APX, EC 1.11.1.11) activity was determined as described by Nakano and Asada (1987).

Dry samples of quinoa seeds were used for the determination of total carbohydrate using the colorimetric method according to Dubois et al. (1956). Crude protein percentage was extracted and determined by Micro-Kjeldahl as well as oil content using methods outlined by A.O.A.C. (1990). The value of total crude protein was calculated by multiplying the total values of total-N by factor 6.25 .

Macro element contents of quinoa seeds were determined according to the methodology of Chapman and Pratt (1978). The seeds N and P contents were determined using Spekol Spectro-colorimeter VEB Carl Zeiss. Potassium (K) was estimated using the flame-photometer set.

\section{Statistical analysis}

A combined analysis for the results of two successive seasons was statistically carried out according to analysis of variance (ANOVA) technique for the split-split plot design experiment with three factors in a completely randomized system using MSTAT-C (1988) computer software package. Least significant difference (LSD) method was used to test the differences among treatment means at 5\% level of probability as described by Snedecor and Cochran (1980).

\section{Results}

\section{Growth parameters}

The effect of proline $(0.5,1.0 \mathrm{mM})$ or trehalose (2.5 and $5.0 \mathrm{mM}$ ) concentrations on growth traits of quinoa when irrigated with different salinity levels in soils supplemented or un-supplemented with compost is presented in Table 3. Compared with the control plants, the irrigation of plants with 3000 and $6000 \mathrm{mg} / \mathrm{L}$ led to significant $(P<0.05)$ decrease in all studied morphological parameters (plant height and fresh and dry weights of shoot). On the contrary, plants grown in the presence of compost showed significant $(P<0.05)$ enhancement in its growth compared to the corresponding control.

All used concentrations of proline or trehalose increased significantly $(P<0.05)$ in the studied growth parameters of quinoa plants in the presence and absence of compost under different salinity levels. The most obvious increase in growth traits was obtained with the highest concentration of both proline and trehalose

Table 3 Morphological criteria of quinoa plants treated with proline or trehalose with (+) and without (-) compost amendment under salinity stress (average of two seasons)

\begin{tabular}{|c|c|c|c|c|c|c|c|c|}
\hline \multirow{2}{*}{$\begin{array}{l}\text { Salinity } \\
\text { (mg/L) }\end{array}$} & \multirow[t]{2}{*}{ Treatment, mM } & & \multicolumn{2}{|c|}{ Shoot length $(\mathrm{cm})$} & \multicolumn{2}{|c|}{$\underline{\text { Shoot FW (g) }}$} & \multicolumn{2}{|c|}{ Shoot DW (g) } \\
\hline & & & - & + & - & + & - & + \\
\hline \multirow[t]{5}{*}{0} & Control & & 16.25 & 22.24 & 8.22 & 10.65 & 0.82 & 1.03 \\
\hline & Proline & 0.5 & 18.73 & 27.64 & 11.08 & 13.16 & 1.28 & 1.59 \\
\hline & & 1.0 & 21.95 & 34.42 & 12.56 & 15.44 & 1.64 & 1.82 \\
\hline & Trehalose & 2.5 & 22.20 & 35.26 & 12.41 & 16.82 & 1.55 & 1.93 \\
\hline & & 5.0 & 25.80 & 37.25 & 14.72 & 18.30 & 1.81 & 2.18 \\
\hline \multirow[t]{5}{*}{3000} & Control & & 14.56 & 18.32 & 5.28 & 6.98 & 0.54 & 0.87 \\
\hline & Proline & 0.5 & 15.36 & 18.95 & 5.71 & 8.28 & 0.78 & 0.93 \\
\hline & & 1.0 & 16.65 & 21.45 & 7.40 & 9.53 & 0.81 & 0.96 \\
\hline & Trehalose & 2.5 & 16.84 & 21.78 & 7.64 & 9.40 & 0.87 & 0.97 \\
\hline & & 5.0 & 17.21 & 23.00 & 6.98 & 11.43 & 0.68 & 1.12 \\
\hline \multirow[t]{5}{*}{6000} & Control & & 11.93 & 13.89 & 3.89 & 4.92 & 0.41 & 0.78 \\
\hline & Proline & 0.5 & 12.69 & 16.32 & 4.69 & 6.68 & 0.62 & 0.79 \\
\hline & & 1.0 & 14.22 & 18.49 & 5.90 & 8.34 & 0.73 & 0.82 \\
\hline & Trehalose & 2.5 & 14.62 & 18.80 & 5.96 & 8.72 & 0.79 & 0.85 \\
\hline & & 5.0 & 15.95 & 20.15 & 6.46 & 8.93 & 0.93 & 0.89 \\
\hline LSD at $5 \%$ & & & 1.35 & & 1.58 & & 0.06 & \\
\hline
\end{tabular}


Table 4 Photosynthetic pigments ( $\mu \mathrm{g} / \mathrm{g}$ fresh weight) of quinoa treated with proline or trehalose with (+) and without (-) compost amendment under salinity stress (average of two seasons)

\begin{tabular}{|c|c|c|c|c|c|c|c|c|c|c|}
\hline \multirow{2}{*}{$\begin{array}{l}\text { Salinity } \\
\text { (mg/L) }\end{array}$} & \multirow{2}{*}{\multicolumn{2}{|c|}{ Treatment, mM }} & \multicolumn{2}{|c|}{ Chlorophyll a } & \multicolumn{2}{|c|}{ Chlorophyll b } & \multicolumn{2}{|c|}{ Carotenoids } & \multicolumn{2}{|c|}{ Total pigments } \\
\hline & & & - & + & - & + & - & + & - & + \\
\hline \multirow[t]{5}{*}{0} & Control & & 18.44 & 20.11 & 4.29 & 4.88 & 4.67 & 5.22 & 27.4 & 30.21 \\
\hline & Proline & 0.5 & 20.17 & 21.15 & 4.84 & 5.93 & 5.42 & 6.31 & 30.43 & 33.39 \\
\hline & & 1.0 & 21.16 & 22.46 & 5.78 & 6.65 & 6.32 & 7.42 & 33.26 & 36.53 \\
\hline & Trehalose & 2.5 & 20.09 & 21.45 & 5.01 & 5.98 & 7.7 & 8.07 & 32.80 & 35.50 \\
\hline & & 5.0 & 22.12 & 23.89 & 6.57 & 7.16 & 5.87 & 6.38 & 34.56 & 37.43 \\
\hline \multirow[t]{5}{*}{3000} & Control & & 16.15 & 16.73 & 2.80 & 3.87 & 2.54 & 2.83 & 21.49 & 23.43 \\
\hline & Proline & 0.5 & 16.58 & 17.06 & 3.31 & 4.28 & 3.18 & 3.16 & 23.07 & 24.50 \\
\hline & & 1.0 & 17.89 & 18.81 & 3.98 & 4.47 & 3.54 & 3.88 & 25.41 & 27.16 \\
\hline & Trehalose & 2.5 & 17.44 & 18.11 & 3.69 & 4.72 & 4.08 & 4.83 & 25.21 & 27.66 \\
\hline & & 5.0 & 18.15 & 19.95 & 5.11 & 5.78 & 3.96 & 5.17 & 27.22 & 30.90 \\
\hline \multirow[t]{5}{*}{6000} & Control & & 14.34 & 14.69 & 2.27 & 3.25 & 2.08 & 2.97 & 18.69 & 20.91 \\
\hline & Proline & 0.5 & 14.73 & 15.21 & 2.51 & 3.73 & 3.01 & 3.54 & 20.25 & 22.48 \\
\hline & & 1.0 & 15.14 & 15.75 & 2.98 & 4.45 & 3.32 & 4.37 & 21.44 & 24.57 \\
\hline & Trehalose & 2.5 & 15.16 & 15.58 & 2.68 & 3.49 & 3.42 & 4.59 & 21.26 & 23.66 \\
\hline & & 5.0 & 16.02 & 16.75 & 3.43 & 4.68 & 2.85 & 3.96 & 22.3 & 25.39 \\
\hline LSD $5 \%$ & & & 1.86 & & 0.45 & & 0.39 & & 2.03 & \\
\hline
\end{tabular}

application in the presence of compost compared to their corresponding control.

\section{Photosynthetic pigments contents}

Quinoa plants irrigated with saline water (3000 and $6000 \mathrm{mg} / \mathrm{L})$ caused gradual significant $(P<0.05)$ decreases in its contents of chlorophyll a, chlorophyll b, carotenoid, and total pigments as compared with their control ones (Table 4). The results also revealed a significant $(P<0.05)$ increase in photosynthetic pigment contents in plants treated with different salinity levels in soils enriched with compost compared to the corresponding plants grown without compost treatment.

Results (Table 4) also revealed that plants treated with either proline $(0.5,1.0 \mathrm{mM})$ or trehalose $(2.5$ and 5.0 $\mathrm{mM}$ ) concentrations under normal conditions or under salinity stress with or without compost treatment significantly $(P<0.05)$ increased its all photosynthetic pigment contents compared to the control and its corresponding control treatments. The maximum increases of the photosynthetic pigments were obtained when trehalose was applied at the rate of $5.0 \mathrm{mM}$ and amended with compost.

\section{Change on osmo-protectants}

Perusal of data in Table 5 for quinoa plants irrigated with saline water (3000 and $6000 \mathrm{mg} / \mathrm{L}$ ) revealed gradual decreases in total soluble sugars (TSS) compared with the control with or without compost addition. This reduction concluded that salt stress may inhibit the photosynthetic
Table 5 Total soluble sugars, proline, and free amino acids (mg/ $100 \mathrm{~g}$ dry weight) of quinoa treated with proline or trehalose with $(+)$ and without $(-)$ compost amendment under salinity stress (average of two seasons)

\begin{tabular}{|c|c|c|c|c|c|c|c|c|}
\hline \multirow{2}{*}{$\begin{array}{l}\text { Salinity } \\
\text { (mg/L) }\end{array}$} & \multicolumn{2}{|c|}{ Treatment, mM } & \multicolumn{2}{|l|}{ TSS } & \multicolumn{2}{|c|}{ Proline } & \multicolumn{2}{|l|}{ FAA } \\
\hline & & & - & + & - & + & - & + \\
\hline & Control & & 1565 & 1638 & 15.83 & 17.13 & 217.65 & 267.14 \\
\hline & Proline & 0.5 & 1594 & 1728 & 17.41 & 20.54 & 241.46 & 292.47 \\
\hline & & 1.0 & 1611 & 1839 & 19.50 & 23.75 & 262.65 & 303.28 \\
\hline & Trehalose & 2.5 & 1643 & 1976 & 24.75 & 27.12 & 298.28 & 298.75 \\
\hline & & 5.0 & 1786 & 1711 & 30.44 & 32.27 & 254.65 & 308.54 \\
\hline \multirow[t]{5}{*}{3000} & Control & & 1365 & 1437 & 27.71 & 29.62 & 240.32 & 314.23 \\
\hline & Proli & 0.5 & 1411 & 1536 & 29.36 & 32.63 & 254.89 & 326.76 \\
\hline & & 1.0 & 1447 & 1576 & 31.01 & 33.65 & 271.65 & 341.14 \\
\hline & Treh & 2.5 & 1487 & 1584 & 33.45 & 35.32 & 320.86 & 361.24 \\
\hline & & 5.0 & 1509 & 1520 & 39.89 & 43.62 & 344.94 & 395.63 \\
\hline \multirow[t]{5}{*}{6000} & Control & & 1401 & 1403 & 39.87 & 41.29 & 315.25 & 352.23 \\
\hline & Proline & 0.5 & 1412 & 1429 & 42.43 & 44.07 & 336.42 & 368 \\
\hline & & 1.0 & 1426 & 1447 & 44.17 & 46.57 & 352.92 & 391.17 \\
\hline & Trehalose & 2.5 & 1444 & 1498 & 47.25 & 50.92 & 395.33 & 415.57 \\
\hline & & 5.0 & 1487 & 1420 & 49.63 & 51.28 & 450.42 & 475.67 \\
\hline \multicolumn{3}{|c|}{ LSD at $5 \%$} & 53.24 & & 1.47 & & 18.71 & \\
\hline
\end{tabular}


activity and/or increased partial utilization of carbohydrates into other metabolic pathways. Salinity stress resulted in a significant improvement in proline and free amino acid levels of quinoa plants.

The data (Table 5) also showed that compost treatment increased significantly $(P<0.05)$ in quinoa plant TSS contents compared to untreated ones (compostfree). The increases in total soluble sugars induce adjustments in the osmotic balance and increase the chlorophyll contents (Table 4) which increased its rate of photosynthesis and carbohydrate synthesis. Compost supplementation positively improved proline and free amino acid content in quinoa plants with increasing salinity stress levels.

Foliar application with different concentrations of proline $(0.5,1.0 \mathrm{mM})$ or trehalose $(2.5$ and $5.0 \mathrm{mM})$ in the presence of compost at different salinity levels induced a significant $(P<0.05)$ increase in the content of osmoprotectants (total soluble sugars, proline, and free amino acids) in quinoa plants; proline accumulation is recorded with stressed plants compared to control plants, especially at higher salt concentration.

\section{Antioxidant enzymes}

The results in Table 6 showed the activities of the antioxidant enzymes (SOD, CAT, POX, and APX) in the shoots of quinoa. The irrigation of quinoa plants with saline water (3000 and $6000 \mathrm{mg} / \mathrm{L})$ caused gradual increases in SOD, CAT, and APX as compared with the control in the absence and presence of compost. The contents of quinoa plants POX activity showed a gradual decrease with increasing salinity levels. In respect to the effect of compost addition, the studied antioxidant enzyme activity increased significantly $(P<0.05)$ compared to stressed and unstressed plants.

The obtained results (Table 6) showed that foliar application of proline $(0.5,1.0 \mathrm{mM})$ or trehalose $(2.5$ and $5.0 \mathrm{mM})$ significantly $(P<0.05)$ increases the SOD, CAT, POX, and APX activities under salt stress and unstressed conditions. The maximum increases of the studied antioxidant enzymes were obtained when trehalose is applied at the rate of $5.0 \mathrm{mM}$ and amended with compost.

\section{Yield components}

Results in Table 7 are presented for the influence of quinoa plant yield parameters by foliar application of proline or trehalose in the presence or absence of compost under different salinity treatment levels. Increasing salinity level resulted in significant $(P<0.05)$ reduction of yield in terms of plant height, number of branches/plant, shoot weight, and seed weight/plant.

Soil supplementation with compost positively improved all studied yield components. The use of compost represents an excellent opportunity to decrease the adverse effect of salinity (abiotic) stress on crop yield.

Applying proline $(0.5,1.0 \mathrm{mM})$ or trehalose $(2.5$ and $5.0 \mathrm{mM}$ ) on quinoa plants showed that both treatments significantly $(P<0.05)$ increased the yield components as compared with the corresponding salinity levels

Table 6 Antioxidant enzyme ( $\mu \mathrm{g} / \mathrm{g}$ fw) of quinoa plants treated with proline or trehalose with (+) and without (-) compost amendment under salinity stress (average of two seasons)

\begin{tabular}{|c|c|c|c|c|c|c|c|c|c|c|}
\hline \multirow{2}{*}{$\begin{array}{l}\text { Salinity } \\
\text { (mg/L) }\end{array}$} & \multirow[t]{2}{*}{ Treatment, mM } & & \multicolumn{2}{|l|}{ SOD } & \multicolumn{2}{|l|}{ CAT } & \multicolumn{2}{|l|}{ POX } & \multicolumn{2}{|l|}{ APX } \\
\hline & & & - & + & - & + & - & + & - & + \\
\hline \multirow[t]{5}{*}{0} & Control & & 18.26 & 20.11 & 55.32 & 60.33 & 31.21 & 36.27 & 7.82 & 9.06 \\
\hline & Proline & 0.5 & 19.69 & 21.43 & 57.93 & 60.84 & 32.56 & 37.08 & 8.91 & 9.88 \\
\hline & & 1.0 & 21.19 & 22.46 & 61.04 & 61.86 & 34.18 & 38.44 & 10.36 & 10.36 \\
\hline & Trehalose & 2.5 & 20.03 & 21.45 & 60.45 & 61.56 & 38.69 & 40.61 & 12.87 & 12.87 \\
\hline & & 5.0 & 22.12 & 23.89 & 61.78 & 63.12 & 40.88 & 44.05 & 13.60 & 13.60 \\
\hline \multirow[t]{5}{*}{3000} & Control & & 25.77 & 26.63 & 60.93 & 60.35 & 23.04 & 31.21 & 12.22 & 13.22 \\
\hline & Proline & 0.5 & 27.31 & 28.45 & 61.81 & 63.70 & 25.91 & 32.29 & 13.09 & 13.73 \\
\hline & & 1.0 & 28.30 & 31.04 & 62.03 & 65.40 & 27.32 & 34.47 & 13.98 & 13.98 \\
\hline & Trehalose & 2.5 & 28.75 & 30.21 & 61.96 & 63.28 & 28.67 & 36.35 & 14.00 & 14.00 \\
\hline & & 5.0 & 30.87 & 32.54 & 63.00 & 72.31 & 32.54 & 37.45 & 14.86 & 14.86 \\
\hline \multirow[t]{5}{*}{6000} & Control & & 33.13 & 36.05 & 62.71 & 62.21 & 15.56 & 23.28 & 14.01 & 14.62 \\
\hline & Proline & 0.5 & 35.44 & 38.86 & 65.87 & 66.67 & 17.25 & 25.09 & 15.47 & 15.82 \\
\hline & & 1.0 & 38.65 & 41.12 & 68.31 & 68.45 & 19.23 & 26.36 & 16.01 & 16.01 \\
\hline & Trehalose & 2.5 & 38.74 & 40.32 & 68.24 & 74.47 & 20.48 & 28.32 & 17.30 & 17.30 \\
\hline & & 5.0 & 40.01 & 44.14 & 71.30 & 80.46 & 23.58 & 29.14 & 19.33 & 19.33 \\
\hline LSD at $5 \%$ & & & 0.65 & & 2.42 & & 1.34 & & 0.79 & \\
\hline
\end{tabular}


Table 7 Yield parameters of quinoa plants treated with proline or trehalose with $(+)$ and without $(-)$ compost amendment under salinity stress (average of two seasons)

\begin{tabular}{|c|c|c|c|c|c|c|c|c|c|c|}
\hline \multirow{2}{*}{$\begin{array}{l}\text { Salinity } \\
\text { (mg/L) }\end{array}$} & \multirow{2}{*}{\multicolumn{2}{|c|}{ Treatment, mM }} & \multicolumn{2}{|c|}{ Plant height $(\mathrm{cm})$} & \multicolumn{2}{|c|}{ Number of branches/plant } & \multicolumn{2}{|c|}{ Shoot weight (g) } & \multicolumn{2}{|c|}{ Seed weight/plant (g) } \\
\hline & & & - & + & - & + & - & + & - & + \\
\hline \multirow[t]{5}{*}{0} & Control & & 43.53 & 46.95 & 11.48 & 14.32 & 7.98 & 8.78 & 4.11 & 5.21 \\
\hline & Proline & 0.5 & 46.43 & 50.96 & 13.43 & 15.86 & 8.43 & 9.56 & 5.42 & 6.40 \\
\hline & & 1.0 & 52.00 & 55.12 & 15.32 & 17.90 & 10.22 & 11.86 & 6.63 & 7.42 \\
\hline & Trehalose & 2.5 & 50.12 & 54.04 & 17.04 & 18.50 & 11.27 & 12.43 & 8.20 & 9.00 \\
\hline & & 5.0 & 55.32 & 58.14 & 16.89 & 18.33 & 10.76 & 11.89 & 7.96 & 8.02 \\
\hline \multirow[t]{5}{*}{3000} & Control & & 38.65 & 40.98 & 9.34 & 11.00 & 5.18 & 6.32 & 3.06 & 4.02 \\
\hline & Proline & 0.5 & 41.46 & 43.05 & 10.25 & 11.65 & 5.61 & 6.32 & 3.64 & 4.19 \\
\hline & & 1.0 & 44.19 & 45.19 & 10.51 & 12.50 & 5.90 & 6.83 & 3.75 & 4.23 \\
\hline & Trehalose & 2.5 & 44.80 & 45.03 & 11.83 & 12.30 & 6.55 & 7.64 & 4.12 & 4.78 \\
\hline & & 5.0 & 45.04 & 47.34 & 10.91 & 12.00 & 5.31 & 6.66 & 3.76 & 3.86 \\
\hline \multirow[t]{5}{*}{6000} & Control & & 24.29 & 28.32 & 7.50 & 8.50 & 3.24 & 4.71 & 2.10 & 2.42 \\
\hline & Proline & 0.5 & 26.98 & 31.15 & 8.46 & 9.24 & 4.76 & 5.38 & 2.53 & 3.48 \\
\hline & & 1.0 & 30.88 & 34.52 & 9.33 & 9.50 & 5.08 & 6.06 & 2.71 & 4.22 \\
\hline & Trehalose & 2.5 & 32.21 & 34.63 & 9.50 & 10.50 & 5.66 & 6.16 & 3.39 & 4.41 \\
\hline & & 5.0 & 35.76 & 40.14 & 9.33 & 11.00 & 5.17 & 5.98 & 2.76 & 3.41 \\
\hline \multicolumn{3}{|c|}{ LSD at $5 \%$} & 3.25 & & 1.16 & & 0.46 & & 0.25 & \\
\hline
\end{tabular}

Table 8 Carbohydrate, protein, and oil percentage in the yielded seeds of quinoa plants treated with proline or trehalose with $(+)$ and without (-) compost amendment under salinity stress (average of two seasons)

\begin{tabular}{|c|c|c|c|c|c|c|c|c|}
\hline \multirow{2}{*}{$\begin{array}{l}\text { Salinity } \\
\text { (mg/L) }\end{array}$} & \multicolumn{2}{|c|}{ Treatment, mM } & \multicolumn{2}{|c|}{ Carbohydrate \% } & \multicolumn{2}{|c|}{ Protein \% } & \multicolumn{2}{|c|}{ Oil \% } \\
\hline & & & - & + & - & + & - & + \\
\hline \multirow[t]{5}{*}{0} & Control & & 56.95 & 60.73 & 13.35 & 13.92 & 6.37 & 6.56 \\
\hline & Proline & 0.5 & 60.86 & 61.15 & 14.58 & 15.19 & 6.52 & 7.16 \\
\hline & & 1.0 & 62.47 & 61.89 & 15.77 & 16.34 & 6.83 & 7.94 \\
\hline & Trehalose & 2.5 & 60.73 & 63.14 & 16.76 & 14.98 & 7.45 & 6.77 \\
\hline & & 5.0 & 63.41 & 65.32 & 17.24 & 19.03 & 7.65 & 9.45 \\
\hline \multirow[t]{5}{*}{3000} & Control & & 53.15 & 52.18 & 11.42 & 11.88 & 5.12 & 6.01 \\
\hline & Proline & 0.5 & 54.73 & 54.82 & 13.51 & 13.96 & 5.98 & 6.52 \\
\hline & & 1.0 & 55.37 & 55.25 & 14.77 & 14.84 & 6.54 & 6.88 \\
\hline & Trehalose & 2.5 & 53.64 & 53.89 & 13.38 & 14.15 & 6.61 & 6.68 \\
\hline & & 5.0 & 57.32 & 56.85 & 15.90 & 16.93 & 7.13 & 7.45 \\
\hline \multirow[t]{5}{*}{6000} & Control & & 45.92 & 49.27 & 9.04 & 10.77 & 4.75 & 5.12 \\
\hline & Proline & 0.5 & 47.53 & 51.53 & 9.96 & 11.83 & 5.07 & 5.86 \\
\hline & & 1.0 & 49.72 & 52.87 & 10.32 & 12.65 & 5.44 & 6.23 \\
\hline & Trehalose & 2.5 & 47.13 & 49.32 & 11.88 & 11.08 & 5.04 & 5.21 \\
\hline & & 5.0 & 51.03 & 55.30 & 12.67 & 14.01 & 6.17 & 6.85 \\
\hline \multicolumn{2}{|c|}{ LSD at $5 \%$} & & 1.75 & & 0.35 & & 0.16 & \\
\hline
\end{tabular}

Table 9 Element contents N, P, and K (\%) in the yielded seeds of quinoa plants treated with proline or trehalose with $(+)$ and without (-) compost amendment under salinity stress (average of two seasons)

\begin{tabular}{|c|c|c|c|c|c|c|c|c|}
\hline \multirow{2}{*}{$\begin{array}{l}\text { Salinity } \\
\text { (mg/L) }\end{array}$} & \multicolumn{2}{|c|}{ Treatment (mM) } & \multicolumn{2}{|l|}{ N\% } & \multicolumn{2}{|l|}{$\mathrm{P} \%$} & \multicolumn{2}{|l|}{$\mathrm{K} \%$} \\
\hline & & & - & + & - & + & - & + \\
\hline & Control & & 2.26 & 2.34 & 0.220 & 0.251 & 0.318 & 0.376 \\
\hline & Proline & 0.5 & 2.32 & 2.42 & 0.231 & 0.258 & 0.332 & 0.371 \\
\hline & & 1.0 & 2.45 & 2.53 & 0.240 & 0.265 & 0.354 & 0.382 \\
\hline & Trehalose & 2.5 & 2.36 & 2.68 & 0.272 & 0.278 & 0.374 & 0.379 \\
\hline & & 5.0 & 2.79 & 2.86 & 0.353 & 0.383 & 0.388 & 0.401 \\
\hline \multirow[t]{5}{*}{3000} & Control & & 2.28 & 2.42 & 0.238 & 0.261 & 0.319 & 0.383 \\
\hline & Proline & 0.5 & 2.33 & 2.49 & 0.245 & 0.273 & 0.332 & 0.397 \\
\hline & & 1.0 & 2.51 & 2.55 & 0.266 & 0.285 & 0.345 & 0.403 \\
\hline & Trehalose & 2.5 & 2.35 & 2.63 & 0.302 & 0.322 & 0.349 & 0.332 \\
\hline & & 5.0 & 2.54 & 2.65 & 0.265 & 0.280 & 0.322 & 0.389 \\
\hline \multirow[t]{5}{*}{6000} & Control & & 2.09 & 2.27 & 0.229 & 0.242 & 0.306 & 0.314 \\
\hline & Proline & 0.5 & 2.14 & 2.32 & 0.256 & 0.274 & 0.364 & 0.386 \\
\hline & & 1.0 & 2.01 & 2.38 & 0.274 & 0.287 & 0.392 & 0.406 \\
\hline & Trehalose & 2.5 & 2.47 & 3.16 & 0.299 & 0.302 & 0.403 & 0.414 \\
\hline & & 5.0 & 3.27 & 3.75 & 0.341 & 0.385 & 0.402 & 0.421 \\
\hline \multicolumn{3}{|c|}{ LSD at $5 \%$} & \multicolumn{2}{|l|}{0.24} & \multicolumn{2}{|l|}{0.0022} & \multicolumn{2}{|l|}{0.0024} \\
\hline
\end{tabular}


particularly in the presence of compost. Trehalose at the rate of $5.0 \mathrm{mM}$ was the most effective on yield trait advancement under the presence of compost as compared to those without compost at the three tested salinity levels.

\section{Changes in carbohydrate, protein, and oil percentage}

The available result in Table 8 represents the effect of salinity stress $(3000$ and $6000 \mathrm{mg} / \mathrm{L}$ ) on quinoa plants treated with proline or trehalose in the absence and presence of compost. Irrigating the plant with salinity reduced the seed nutritive value. The foliar application of proline or trehalose in addition or absence of compost on quinoa plants grown ameliorates the adverse effect of salinity on seed nutritive values in terms of carbohydrate, protein, and oil percentage. Compost addition with trehalose gave the best results compared to that recoded with un-supplemented.

\section{Changes in mineral contents of the yielded seeds}

Quinoa plants yielded seeds' results subjected to salinity stress (3000 and $6000 \mathrm{mg} / \mathrm{L})$ in the absence and presence of compost and/or treated with proline or trehalose are presented in Table 9. Irrigation of the plants with salinity induced non-significant increase in the macroelements content $(\mathrm{N}, \mathrm{P}$, and $\mathrm{K})$ in the yielded seeds in response to $3000 \mathrm{mg} / \mathrm{L}$, meanwhile the highest salinity level $(6000 \mathrm{mg} / \mathrm{L})$ induced a significant $(P<0.05)$ decrease in the detected macro-elements compared to control plants.

Soil amendment with compost increases the availability of plant nutrients, improves physical properties, and stimulates biological activities. The available results (Table 9) showed that an addition of compost to soil provided higher total $\mathrm{N}, \mathrm{K}$, and available $\mathrm{P}$ contents than control of quinoa plants.

Furthermore, proline and trehalose in the presence and absence of compost are generally induced by an increase in total N, P, and $\mathrm{K}$ contents of quinoa seeds. It could be concluded that the stimulative effect of proline and trehalose to increase $\mathrm{N}$ content came through enhancing the biosynthesis of free amino acids (Table 5). The relatively large quantity of macroelements required for plant growth and development (Table 3) and photosynthetic pigments (Table 4) was obtained in plants treated with proline and trehalose when compost is added to the experimental soil.

\section{Discussion}

\section{Growth parameters}

The effect of proline or trehalose on growth traits of quinoa when irrigated with different salinity levels in soils supplemented or un-supplemented with compost is presented in Table 3. Compared with the control plants, the irrigation of plants with 3000 and $6000 \mathrm{mg} / \mathrm{L}$ led to a significant decrease in all studied morphological parameters (plant height and fresh and dry weights of shoot). These results might be due to the inhibitory effect of salinity through reduced water absorption and metabolic activities or due to $\mathrm{Na}^{+}$and $\mathrm{Cl}^{-}$toxicity and nutrient deficiency caused by ion interference. The obtained results are consistent with results recorded by Hussein et al. (2019) found that salinity level of $4000 \mathrm{ppm}$ reduced plant height, leaves number, leave area/plant, and dry weight of shoot, leaves, and spike/plant of barley plant. Also, Abdallah et al. (2020) reported that all growth criteria of wheat cultivars are affected with salinity levels due to salt stress effects on plant cells' functions in terms of different enzymes and metabolism functions in the cell.

On the contrary, plants grown in the presence of compost showed significant enhancement in its growth compared to the corresponding control. The role of compost in increasing quinoa growth may have resulted from endogenous growth promoters produced by microorganism which enhance the mobilization of nutrient through increasing cell divisions and/or increasing the differentiation of the vascular connection between the axillary buds and the main stem. In this regard, Kirakosyan et al. (2006) stated that auxin in forms of IAA produced from fungi (mutant Penicillium) enhanced the growth of rice plant under salinity stress. Also, El Sebai et al. (2016) who worked on quinoa plants reported that the improved growth characteristics resulted from increased application rate of compost and attributed this improvement to the enhanced decomposition of organic matter and mineralization of nutrients.

All used concentrations of proline $(0.5,1.0 \mathrm{mM})$ or trehalose $(2.5$ and $5.0 \mathrm{mM})$ concentrations increased significantly $(P<0.05)$ the studied growth parameters of quinoa plants in the presence and absence of compost under different salinity levels.

Concerning the effect of proline, Taie et al. (2013) found a similar trend of increased growth parameters (plant height, number of leaves, and shoot dry weight). These increases in growth attributed to low and high proline concentrations that have a role in protecting enzymes, structures of proteins, and organelle membranes (Hoque et al. 2007). These results are also supported by findings of Ashraf and Foolad (2007) who suggested that proline supplies energy for growth and survival thereby helping the plant to overcome stresses. Also, Abdallah and El-Bassiouny (2016) found that exogenous application of proline led to marked increases in growth characteristics (plant height, shoot, root fresh, and dry weight) on quinoa plants. They added that proline treatment induced an increase in apical meristem and cell division (Ali et al. 2008). 
For trehalose treatment effect, Zeid (2009) reported that trehalose is nontoxic molecules as compatible solutes able to accumulate at high concentrations in the cytoplasm and participate in turgor maintenance. It also protects the macromolecular structures against the destabilizing effect of anhydrobiotic conditions under salinity stress. Gaff (1996) referred this action of trehalose in transgenic plants in improving water relations and desiccation tolerance to osmoregulation and stomatal closing when drought stress became mild. The same trend of trehalose application was reported by Alam et al. (2014) with different Brassica species.

\section{Photosynthetic pigments contents}

Quinoa plants irrigated with saline water (3000 and $6000 \mathrm{mg} / \mathrm{L}$ ) caused gradual significant decreases in its contents of chlorophyll a, chlorophyll b, carotenoid, and total pigments as compared with their control ones (Table 4). Similar results were recorded by Sadak et al. (2012) on and Abdallah et al. (2020) on wheat cultivars. Kosová et al. (2011) concluded that enzymes' activities which can be considered as a secondary effect of the reduced $\mathrm{CO}_{2}$ partial pressure resulted from stomatal closure in leaves were responsible for the inhibitory effect of salinity stress on the photosynthetic pigments. Moreover, under salinity stress, the same effect (a reduction in photosynthesis and growth) is induced by the increase in free radicals (ROS) in chloroplasts and destruction of chlorophyll molecules (Sadak et al. 2020). In addition, Rady et al. (2013) referred the adverse effect of salt stress to the chlorophyllase enzymes responsible for chlorophyll degradation.

The results (Table 4) also revealed a significant $(P<$ $0.05)$ increase in photosynthetic pigments contents in plants grown in soils enriched with compost compared to the corresponding plants grown without compost treatment. This is consistent with compost effects on stomatal opening that is confirmed with Nguyen et al.'s (2012) and El Sebai et al.'s (2016) findings who reported that the adverse effects of salinity stress are ameliorated in terms of increased chlorophyll contents with compost containing microorganism. It is worth noting that carotenoid content was significantly higher in quinoa plants with compost treatment in combination with different concentrations of salt compared to other plants without compost. The increased chlorophyll content accompanied to the enhancement in plant capacity to reduce the damaging effect of ROS may be attributed to the increased carotenoids, which may play a role as a free radical scavenger, with compost treatment.

Results also revealed that plants treated with either proline $(0.5,1.0 \mathrm{mM})$ or trehalose $(2.5$ and $5.0 \mathrm{mM})$ concentrations under normal conditions or under salinity stress with or without compost treatment significantly $(P$
$<0.05)$ increased its all photosynthetic pigment contents compared to the control and its corresponding control treatments.

Concerning the effect of proline application, Yan et al. (2011) explored the role of proline in possessing some defensive mechanisms for damage of plants in addition to its function as a nutrient under salt stress. These defense mechanisms played a role in promoting photosynthesis, maintaining enzyme activity, and scavenging ROS. Taie et al. (2013) found that proline exogenous application was capable of overcoming the harmful effects of salinity on photosynthetic pigments.

Regarding trehalose treatments, Abdalla et al. (2016) found that presoaking rice seeds in trehalose produced a significant increase in photosynthetic pigments compared to untreated resultant plants. Moreover, Ali and Ashraf (2011) attributed the increment in biomass and some key photosynthetic attributes to a specific increase in Rubisco activity, resulted from increased amounts of Rubisco protein, chlorophyll, and the light-harvesting apparatus.

\section{Change on osmo-protectants}

Perusal of data in Table 5 for quinoa plants irrigated with saline water (3000 and $6000 \mathrm{mg} / \mathrm{L}$ ) revealed gradual decreases in total soluble sugars (TSS) compared with the control with or without compost addition. Similar results have been reached by Rady et al. (2011) in sunflower cultivars. Salinity stress resulted in a significant improvement in proline and free amino acid levels of quinoa plants. These results are supported by other results recorded by El-Bassiouny and Abdel-Monem (2016) who found that salinity stress was capable of acting as activators of free amino acids accumulation in sunflower plants. Moreover, Abdallah et al. (2016) reported that proline plays crucial protecting roles from drought-osmotic stresses in terms of osmotic adjustment, stabilization, and protection of enzymes, proteins, and membranes and the reduction in lipid membranes oxidation. Mitysik et al. (2002) recorded that increased osmolytes (proline and free amino acids) protect macromolecules via stabilizing protein structure and/or scavenging ROS produced under stress conditions.

Data also showed that compost treatment increased significantly quinoa plants TSS contents compared to untreated ones (compost-free). The processes involved of compost lead to increased rates of photosynthesis and of carbon compounds to the plants (El-Sebai et al. 2016). In addition, it is mentioned that the increase in total soluble sugars induces adjustments in the osmotic balance and increases the chlorophyll contents which increased its rate of photosynthesis and carbohydrate synthesis. Compost supplementation positively improved proline and free amino acid content in quinoa plants 
with increasing salinity stress level (Table 5). These results are in agreement with plants by El-Sebai et al. (2016) on quinoa and Banerjee et al. (2012) on mustard plant.

Foliar application with different concentrations of proline $(0.5,1.0 \mathrm{mM})$ or trehalose $(2.5$ and $5.0 \mathrm{mM})$ in the presence of compost at different salinity levels induced a significant $(P<0.05)$ increase in the content of osmoprotectants (total soluble sugars, proline, and free amino acids) in quinoa plants, proline accumulation recorded with stressed plants compared to control plants especially at higher salt concentration. These effects are in line with the recorded results by Noreen et al. (2018) who denoted that copper stressed wheat plants reduced ROS content and increased proline accumulation with proline treatments and Yang et al. (2014) on saltstressed Arabidopsis plants treated with trehalose which elevated its total soluble sugars. Ibrahim and Abdellatif (2016) found that foliar application of trehalose improved plant osmotic adjustment ( free amino acids, reducing sugars, and total soluble sugars) on wheat leaves under water stress.

\section{Antioxidant enzymes}

The results in Table 6 showed the activities of the antioxidant enzymes (SOD, CAT, POX, and APX) in the shoots of quinoa. The irrigation of quinoa plants with saline water $(3000$ and $6000 \mathrm{mg} / \mathrm{L})$ caused gradual increases in SOD, CAT, and APX and gradual decrease in POX activity as compared with the control in the absence and presence of compost. In terms of salinity effect, these results were supported by the results of El-Bassiouny and Sadak (2015). In this concern, Abdallah et al. (2020) stated that the increase in antioxidant enzymes could be considered as an indicator to the increased production of ROS and stimulation for a protective mechanism to reduce oxidative damage resulted from plant responses to stress. Multiple antioxidant enzyme systems are involved in the enzymatic scavenging of ROS.

An addition of compost to the soil increased significantly the studied antioxidant enzyme activity compared to stressed and unstressed plants. Similar effects were obtained by El-Sebai et al. (2016) who found that compost increases tolerance of quinoa plants to salinity stress through increasing the activity of antioxidant enzymes (CAT, SOD, POX, and APX activities) as compared with the corresponding control. Also, Shaukat et al. (2006) recorded increments in POX activity on Triticum aestivum as a result of inoculating the plants with Pseudomonas strains.

The obtained results showed that foliar application of proline $(0.5$ and $1.0 \mathrm{mM})$ or trehalose $(2.5$ and $5.0 \mathrm{mM})$ significantly increases the SOD, CAT, POX, and APX activities under salt stress and unstressed conditions.
The obtained results came in line with the findings of Nounjan et al. (2012) who found that the SOD activity was considerably increased to convert $\mathrm{O}^{2}$ to $\mathrm{H}_{2} \mathrm{O}_{2}$ under salinity stress, which is detoxified thereafter by POX, APX, and CAT. However, enhanced CAT activity in trehalose considered an efficient $\mathrm{H}_{2} \mathrm{O}_{2}$ scavenging mechanism that contributes to tolerance of salt-induced oxidative stress (Dolatabadian and Jouneghani 2009). Also, Abdallah and El- Bassiouny (2016) reported that proline plays a regulatory role in the activity and function of SOD, CAT, and POX enzymes in plant cells as well as in their participation in metabolic response development in response to environmental factors. The antioxidant enzyme system (the first defense line) provides vital protection against oxidative damage through scavenging the active oxygen species $\left(\mathrm{O}_{-}, \mathrm{OH}_{-}\right.$, and $\mathrm{H}_{2} \mathrm{O}_{2}$ ) within stressed plant cells (Sharma and Dubey 2007).

\section{Yield components}

The response of quinoa plants yields parameters by foliar application of proline or trehalose in the presence or absence of compost under different salinity treatment levels (Table 7).

The noticed reduction in yield traits may be attributed to the inhibitory effect of salinity on growth (Table 3) which reflected on the yield as well as the disturbance in mineral uptake (El Sebai et al. 2016).

The use of compost represents an excellent opportunity to decrease the adverse effect of salinity stress and positively improved all studied yield components. El Sebai et al. (2016) reported that soil enriched with compost significantly increased the yield component of quinoa plants under water stress conditions Also, Rady et al. (2016) reported that an addition of compost improved the soil characteristics and consequently pod and seed yields of common bean.

Applying proline or trehalose on quinoa plants at different concentrations showed that both treatments significantly $(P<0.05)$ increased the yield components as compared with the corresponding salinity levels particularly in the presence of compost. Sadak (2016) found that the treatment of fenugreek plants with different concentrations of trehalose led to an increase in its yield components. Moreover, Abdallah and El-Bassiouny (2016) found that the treatment of quinoa plant with proline at different concentrations stimulated its yield parameters.

\section{Changes in carbohydrate, protein, and oil percentage}

The results in Table 8 revealed that irrigation of plants with saline solution reduced the seed nutritive value. The effect of salinity stress was in good harmony with the results obtained Ramadan et al. (2019) on sunflower. 
The foliar application of proline or trehalose in addition or absence of compost on quinoa plants grown ameliorates the adverse effect of salinity on seed nutritive values in terms of carbohydrate, protein, and oil percentage. Compost addition with trehalose gave the best results compared to that recoded with un-supplemented.

As regards to the effect of compost, similar findings were obtained by El-Sebai et al. (2016) who stated that adding compost to the soil significantly increased total carbohydrate, protein, and oil percentage contents of quinoa yielded seeds.

Similar to the findings with our data, regarding the effect of proline treatment, Abdallah and El-Bassiouny (2016) found also that the application of proline increased the nutritional values of the yielded seed of quinoa plants in terms of carbohydrate and protein percentage. Also, Taie et al. (2013) on faba bean plants showed that treatment with proline significantly increased both total carbohydrates and total soluble carbohydrates compared to the control.

The observed increase in nutritive in seeds in response to trehalose treatments was in accordance with the studied of Elewa et al. (2017) induced that trehalose treatments at different levels caused marked increases in carbohydrate, protein, oil, and antioxidants of the yielded seeds either in non-stressed or drought-stressed plants relatively to the control ones. They added that trehalose serves as a carbohydrate storage molecule as well as a transport sugar (Muller et al., 1999). In addition, underexposure of plants to stress, trehalose can replace hydrogen bonding through polar residues resulting in preventing protein denaturation and fusion of membranes responsible for protein and membrane stability (Iturriaga et al. 2009).

\section{Changes in mineral contents in yielded seeds}

Results in Table 9 showed that plants irrigated with high salinity levels $(6000 \mathrm{mg} / \mathrm{L})$ reduced the macro-elements content $(\mathrm{N}, \mathrm{P}$, and $\mathrm{K})$ in the yielded seeds. In this respect, as reviewed and discussed by Ramadan et al. (2019), salt stress disrupts the availability, competitive uptake, and translocation of nutrients to the plant parts. Interference of other elements with excessive concentrations of $\mathrm{Na}$ and $\mathrm{Cl}$ ions present in the soil causes imbalanced plant nutrition. These results can be disproved to others on the base that higher concentrations of sodium chloride $(\mathrm{NaCl})$ as the prevailing salt in the soil lowers its osmotic potential that induce a reduction in the availability of water and minerals to root cells resulting in osmotic and ionic effects on plants (Khan et al., 2012).

Soil amendment with compost increases the availability of plant nutrients, improves physical properties, and stimulates biological activities. The data obtained herein are in harmony with those of by El-Naggar (2010) who found that the organic compost applications increased the uptake of N, P, and K of Narcissus tazetta L.

Furthermore, proline and trehalose in the presence and absence of compost generally induced an increase in total N, P, and $\mathrm{K}$ contents of quinoa seeds. In support of the above result of increased macro-element content with proline treatment, Dawood et al. (2014) on Vicia faba plants stated that foliar treatment of proline improved the toxicity of stress water by increasing the inorganic nutrients $(\mathrm{N}, \mathrm{P}, \mathrm{K}$, and $\mathrm{Ca})$ as well as the ratio of $\mathrm{K}^{+} / \mathrm{Na}^{+}$. Also, Ali et al. (2008) on maize cultivars stated that proline increased ion uptake and regulated their transportation.

Elewa et al. (2017) found that different levels of treatments of trehalose gave marked increases in nitrogen, phosphorous, and potassium contents of quinoa plants. In another study, a similar effect was obtained by Ajay et al. (2002) on transgenic and non-transgenic rice plants and Yang et al. (2014) on Arabidopsis.

\section{Conclusion}

Soil supplementation with compost improved quinoa growth, yield, and produced seeds with high nutritional value when the plants foliar sprayed with proline and/or trehalose under saline water stress conditions.

\section{Abbreviations \\ TSS: Total soluble sugar; FAA: Free amino acids; CAT: Catalase; \\ SOD: Superoxide dismutase; POX: Peroxidase; APX: Ascorbate peroxidase}

\section{Acknowledgements}

Not applicable.

\section{Authors' contributions}

Maha Mohamed Shater Abd Allah designed the study, participated in the physiological and biochemical analysis, wrote and reviewed the manuscript, and read and approved the final manuscript. Talaat N. El Sebai designed the study and farming the plants and follow-up, took the sample and statistical data analysis, and read and approved the final manuscript. Amany Abd ElMohsen Ramadan participated in the physiological and biochemical analysis, wrote and reviewed the manuscript, and read and approved the final manuscript. Hala Mohamed Safwat El-Bassiouny designed the study, performed the experiment, participated in the physiological and biochemical analysis, and read and reviewed the manuscript. The authors read and approved the final manuscript.

\section{Funding}

Not applicable.

\section{Availability of data and materials}

The datasets used and/or analyzed during the current study are available from the corresponding author on reasonable request.

Ethics approval and consent to participate Not applicable.

Consent for publication

Not applicable.

Competing interests

The authors declare that they have no competing interests 


\section{Author details}

'Department of Botany, Agricultural and Biological Research Division, National Research Centre, 33 El Bohouth Street, P.O. Box 12622, Giza, Dokki, Egypt. ${ }^{2}$ Agricultural Microbiology Department, Agricultural and Biological Research Division, National Research Centre, 33 El Bohouth Street, P.O. Box 12622, Giza, Dokki, Egypt.

Received: 21 April 2020 Accepted: 4 June 2020

Published online: 15 June 2020

\section{References}

A.O.A.C. (1990) Official Methods of Analysis.20 $20^{\text {th }}$ edition. Association of Official Analytical Chemists, Arlington, Virginia, U.S.A.

Abdallah MMS, Abdelgawad ZA, El-Bassiouny HMS (2016) Alleviation of the adverse effects of salinity stress using trehalose in two rice varieties. South African Journal of Botany 103:275-282. https://doi.org/10.1016/j.sajb.2015.09.019

Abdallah MMS, El-Bassiouny HMS (2016) Impact of exogenous proline or tyrosine on growth, some biochemical aspects and yield components of quinoa plant grown in sandy soil. International Journal of Phar. Tec. 9(7):12-23 https://www.researchgate.net/publication/309042526

Abdallah MMS, Ramadan AA, El-Bassiouny HMS, Bakry BA (2020) Regulation of antioxidant system in wheat cultivars by using chitosan or salicylic acid to improve growth and yield under salinity stress Asian J. of. Plant Sciences. 19(2):114-126. https://doi.org/10.3923/ajps.2020.114.126

Ajay KG, Ju-Kon K, Thomas GO, Anil PR, Yang DCh, Leon VK and Ray JW (2002). Trehalose accumulation in rice plants confers high tolerance levels to different abiotic stresses. Proc. Natl. Acad. Sci .USA. 10; 99(25): 15898-15903. doi: https://doi.org/10.1073/pnas.252637799

Alam MDM, Nahar K, Hasanuzzaman M, Fujita M (2014) Trehalose-induced drought stress tolerance: a comparative study among different Brassica species. POJ 7(4):271-283 https://www.pomics.com/hassanuzzaman_7_4_2 014_271_283.pdf

Ali Q, Ashraf M (2011) Induction of drought tolerance in maize (Zea mays, L.) due to exogenous application of trehalose: growth, photosynthesis, water relations and oxidative defense mechanism. Journal of Agronomy and Crop Science 197:258-271. https://doi.org/10.1111/j.1439-037X.2010.00463.x

Ali QM, Ashraf M, Shahbaz M, Humera M (2008) Ameliorating effect of foliar applied proline on nutrient uptake in water stressed maize (Zea mays $\mathrm{L}$.) plants. Pakistan Journal of Botany 40:211-219 www.pakbs.org/pjbot/PDFs/4 0(1)/PJB40(1)211.pdf

Almeida AM, Silva AB, Aráujo SS, Cardoso LA, Santos DM (2007) Responses to water withdrawal of tobacco plants genetically engineered with the AtTPS1 gene: a special reference to photosynthetic parameters. Euphytica 154:113-126

Ashraf M, Foolad MR (2007) Roles of glycinebetaine and proline in improving plant abiotic stress tolerance. Envir. and Exp. Bot. 59:206-216

Banerjee A, Datta JK, Mondal NK (2012) Biochemical changes in leaves of mustard under the influence of different fertilizers and cycocel. Journal of Agricultural Technology 8(4):1397-1411 http://www.ijat-aatsea.com

Bates LS, Waldan RP, Teare LD (1973) Rapid determination of free proline under water stress studies. Plant Soil 39:205-207. https://doi.org/10.1007/ BF00018060

Beltagi MS (2008) Exogenous ascorbic acid (Vitamin C) induced anabolic changes for salt tolerance in chick pea (Cicer arietinum L.) plants. African J. of Plant Sci. , 2(10): 118-123. https://www.researchgate.net/publication/228661116_

Chapman HD, Pratt PF (1978) Methods of analysis for soil, plant and water. Agric. Sci. Dept. Univ. of California USA 309. Chem. 36:345-347

Chen JX and Wang XF (2006) Plant Physiology Experimental Guide. 24-25. Higher Education Press, Beijing, pp. 55-56. https://www.scirp.org/

Dawood MG, Taie HAA, Nassar RMA, Abdelhamid MT, Schmidhalter U (2014) The changes induced in the physiological, biochemical and anatomical characteristics of Vicia faba by the exogenous application of proline under seawater stress. South African Journal of Botany 93:54-63. https://doi.org/10. 1016/j.sajb.2014.03.002

Dolatabadian A and Jouneghani RJ S (2009) Impact of exogenous ascorbic acid on antioxidant activity and some physiological traits of common been subjected to salinity stress. Notulae Botanicae Horti. Agrobotanici ClujNapoca, 37(2): 165-172. DOI: https://doi.org/10.15835/nbha3723406

Dubois M, Guilles KA, Hamilton JK, Rebers PA, Smith F (1956) Colorimetric method for determination of sugars and related substances. Anal. Chem. 28: 350-356. https://doi.org/10.1021/acs.analchem.6b00779
El-Bassiouny HMS and Sadak, M Sh (2015) Impact of foliar application of ascorbic acid and a-tocopherol on antioxidant activity and some biochemical aspects of flax cultivars under salinity stress. Acta biol. Colomb., 20(2): 209-222. Doi: https://doi.org/10.15446/abc.v20n2.43868

El-Bassiouny HMS, Abdel-Monem AA (2016) (2016) Role of Tryptophan or Prozac (5-hydroxytryptamine) on some osmolytes and antioxidant defense system of sunflower cultivars grown in Saline soil. International Journal of Chem Tech Research. 9(6):107-120 http://www.sphinxsai.com/2016/ch_vol9_no6/1/ (107-120)V9N6CT.pdf

Elewa TA, Sadak M Sh and Dawood MG (2017) Improving drought tolerance of quinoa plant by foliar treatment of trehalose. Agric. Eng. Int.: CIGR Journal Special issue, 245-254. https://cigrjournal.org/index.php/Ejounral/article/ view/4539/0

El-Naggar AH (2010) Effect of biofertilizer, organic compost and mineral fertilizers on the growth, flowering and bulbs production of Narcissus tazetta, L. J. Agric. \& Env. Sci. Alex. Univ. Egypt 9(1):24-52 https://pdfs.semanticscholar. org/5459/

El-Sebai TN, Abdallah MMS, El-Bassiouny HMS, Ibrahim FM (2016) Amelioration of the adverse effects of salinity stress by using compost, Nigella sativa extract or ascorbic acid in quinoa plants. International Journal of Pharm. Tech. Research 9(6):127-144 https:/www.researchgate.net/publication/306328400

El-Sebai T.N.M., . Khattab A.A, Abd-El Rahim W.M., and Moawad H., 2014. Enhancement of rice straw composting using UV induced mutants of Penicillium strain. World Academy of Science, Engineering and Technology International Journal of Biological, Biomolecular, Agricultural, Food and Biotechnological Engineering, 8(8): 949-953.

FAO (2013) Home-international Year of Quinoa 2013. Retrieve from. http://www. fao.org/quinoa-2013/en

FAO (2014) The State of Food Insecurity in the World:2014 http://www.fao.org/ news/story/

Fernandez O, Béthencourt L, Quero A, Sangwan RS, Clément C (2010) Trehalose and plant stress responses: friend or foe? Trends in Plant Science 15:409-417 https://www.sciencedirect.com/science/article/pii/S1360138510000725

Gaff D (1996) Tobacco-plant dessication tolerance. Nature (London) 382:502

Gonzalez JA, Konishi Y, Bruno M, Valoy M, Pradoc FE (2012) Inter-relationships among seed yield, total protein and amino acid composition of ten quinoa (Chenopodium quinoa) cultivars from two different agro-ecological regions. J. Sci. Food Agric. 92:1222-1229. https://doi.org/10.1002/jsfa.4686

Homme PM, Gonzalez B and Billard J (1992) Carbohydrate content, frutane and sucrose enzyme activities in roots, stubble and leaves of rye grass (Lolium perenne, L.) as affected by sources/link modification after cutting. J. Plant Physiol., 140: 282-291.

Hoque MA, Banu MN, Okuma E, Amako K, Nakamura Y, Shimoishi Y, Murata Y (2007) Exogenous proline and glycinebetaine increase $\mathrm{NaCl}$-induced ascorbate-glutathione cycle enzyme activities, and proline improve salt tolerance more than glycinebetaine in tobacco Bright Yellow-2 suspensioncultured cells. J. Plant Physio. 164:1457-1468 https://www.ncbi.nlm.nih.gov

Hussein MM, Sabbour MM, El-Faham SY (2019) Arginine and pyruvic acid and its effects on chlorophyll, carotenoids contents, insect infestations and growth of barley plants grown under salinity conditions. Bioscience Research 16(1): 216-225 https://www.isisn.org/

Ibrahim HA, Abdellatif YMR (2016) Effect of maltose and trehalose on growth, yield and some biochemical components of wheat plant under water stress. Annals of Agricultural Sciences. 61(2):267-274. https://doi.org/10.1016/j.aoas. 2016.05.002

Iturriaga G, Suarez R, Nova-Franco B (2009) Trehalose metabolism: rom osmoprotection to signaling. International Journal of Molecular Sciences 10(9):3793-3810. https://doi.org/10.3390/ijms10093793

Jain NK, Roy I (2009) Effect of trehalose on protein structure. Protein Science 18: 24-36. https://doi.org/10.1002/pro.3

Khan MN, Siddiqui MH, Mohammad F, Naeem M (2012) Interactive role of nitric oxide and calcium chloride in enhancing tolerance to salt stress. Nitric Oxide 27:210-218. https://doi.org/10.1016/j.niox.2012.07.005

Kirakosyan A, Kaufman PB, Chang SC, Warber S, Bolling S, Vardapetyan H (2006) Regulation of isoavone production in hydroponically grown Pueraria montana (kudzu) by cork pieces, XAD-4, and methyl jasmonate. Plant Cell Rep. 25:1387-1391. https://doi.org/10.1007/s00299-006-0198-2

Kosová K, Vitámvás P, Prášil IT, Renaut J (2011) Plant proteome changes under abiotic stress contribution of proteomics studies to understanding plant stress response. Journal of Proteomics 74:1301-1322. https://doi.org/10.1016/ j.jprot.2011.02.006 
Kumar KB, Khan PA (1982) Peroxidase and polyphenol oxidase in excised ragi (Eleusine coracana Cv. PR 202) leaves during senescence. Indian J. Exp. Bot 20:412-416 https://www.scirp.org/(S(351jmbntvnsjt1aadkposzje))/reference/ ReferencesPapers.aspx

Lichtenthaler HK, Buschmann C (2001) Chlorophylls and carotenoids: measurement and characterization by UV-VIS spectroscopy. In: Wrolstad RE, Acree TE, An H, Decker EA, Penner MH, Reid DS, Schwartz SJ, Shoemaker CF, Sporns $P$ (eds) Current protocols in food analytical chemistry (CPFA). Wiley, New York, pp F4.3.1-F4.3.8. https://doi.org/10.1002/0471142913.faf0403s01

Martinez EA, Fuentes F, Bazile D (2015) History of Quinoa: its origin, domestication, diversification and cultivation with particular reference to the chilean context. In: Murphy K, Matanguihan J (eds) Quinoa: Improvement and Sustainable Production. Wiley-Blackwell, Hoboken, pp 19-24. https://doi. org/10.1002/9781118628041.ch2

Mitysik JB, Alia B, Mohanty P (2002) Molecular mechanism of quenching of reactive oxygen species by proline under stress in plants. Current Science 82 $525-532$

MSTAT-C (1988) A microcomputer program for the design. Michigan State University East Lansing, Arrangement and analysis of agronomic research

Muller J, Wiernken A, Aschbacher R (1999) Trehalose metabolism in sugar sensing and plant development. Plant Science 147(1):37-47. https://doi.org/10.1042/ BST0330276

Nakano Y, Asada K (1987) Purification of ascorbate peroxidase in spinach chloroplast; its inactivation in ascorbate depleted medium and reactivation by monodehydroascorbate radical. Plant Cell Physiol. 28:131-140

Nanjo T, Fujita M, Seki M, Kato T, Tabata S, Shinozaki K (2003) Toxicity of free proline revealed in an Arabidopsis T-DNA-tagged mutant deficient in proline dehydrogenase. Plant and Cell Physiology 44:541-548. https://doi. org/10.1093/pcp/pcg066

Nguyen TT, Fuentes S, and Marschner P (2012) Effects of compost on water availability and gas exchange in tomato during drought and recovery. Plant Soil Environ. 58(11): 495-502. DOl: https://doi.org/10.17221/403/2012-PSE

Noreen S, Akhter MS, Yaamin T, Arfan M (2018) The ameliorative effects of exogenously applied proline on physiological and biochemical parameters of wheat (Triticum aestivum L.) crop under copper stress conditionJournal of Plant Interactions, 13:1, 221-230. https://doi.org/10.1080/17429145.2018. 1437480

Nounjan N, Nghiab PT, Theerakulpisuta P (2012) Exogenous proline and trehalose promote recovery of rice seedlings from salt-stress and differentially modulate antioxidant enzymes and expression of related genes. Journal of Plant Physiology 169:596-604 https://www.researchgate.net/publication/324974291

Nowak V, Du J, Charrondiere UR (2016) Assessment of the nutritional composition of quinoa (Chenopodium quinoa Willd.). Food Chem. 193:47-54. https://doi.org/10.1016/j.foodchem.2015.02.111

Rady MM, Sadak MS, El-Bassiouny HMS, Abd El-Monem AA (2011) Alleviation the adverse effects of salinity stress in sunflower cultivars using nicotinamide and a-tocopherol. Australian Journal of Basic and Applied Sciences 5(10):342-355

Rady MM, Semida WM, Hemida KA, Abdelhamid MT (2016) The effect of compost on growth and yield of Phaseolus vulgaris plants grown under saline soil. Int. J. Recycl. Org. Waste. Agricult. 5:311-321. https://doi.org/10. 1007/s40093-016-0141-7

Rady MM, Varma CB, Howladar SM (2013) Common bean (Phaseolus vulgaris, L.) seedlings overcome $\mathrm{NaCl}$ stress as a result of presoaking in Moringa oleifera leaf extract. Sci. Hortic. 162:63-70

Ramadan AA, Abd Elhamid EM, Sadak MS (2019) Comparative study for the effect of arginine and sodium nitroprusside on sunflower plants grown under salinity stress conditions. Bulletin of the National Research Centre 43:118-129. https://doi.org/10.1186/s42269-019-0156-0

Ramadan AA, El-Bassiouny HMS, Bakry BA, Abdallah MMS and El-Enany MAM (2020) Growth, Yield and Biochemical Changes of Soybean Plant in Response to Iron and Magnesium Oxide Nanoparticles. Pakistan J Biological Sciences. 23: 406-417. DOI: 10.3923/pjbs.2020.406.417

Rontein D, Basset G, Hanson AD (2002) Metabolic engineering of osmoprotectant accumulation in plants. Metabolic Engineering 4:49-56 https://www. researchgate.net/publication/11557561

Sadak MS (2016) Mitigation of drought stress on fenugreek plant by foliar application of trehalose. Inter. J. of Chem. Tech. Res. 9(2):147-155 www. researchgate.net/publication/301920704

Sadak MS, El-Enany MAM, Bakry BA, Abdallah MMS, El-Bassiouny HMS (2020) Signal Molecules Improving Growth. Yield and Biochemical Aspects of Wheat
Cultivars under Water Stress Asian J of Plant Sciences. 19(1):35-53. https:// doi.org/10.3923/ajps.2020.35.53

Sadak M Sh, Abd El-Monem AA, El-Bassiouny HMS, and Badr N M (2012) Physiological response of sunflower (Helianthus annuus L.) to exogenous arginine and putrescine treatments under salinity stressJournal of Applied Sciences Research J. Appl. Sci. Res., 8(10): 4943-4957. https://www. researchgate.net/publication/286656094

Sadak M Sh, El-Bassiouny HMS and Dawood MG (2019) Role of trehalose on antioxidant defense system and some osmolytes of quinoa plants under water deficit Bulletin of the National Research Centre, 43:5. https://bnrc. springeropen.com/articles/10.1186/s42269-018-0039-9

Sharma P, Dubey RS (2007) Involvement of oxidative stress and role of antioxidative defense system in growing rice seedlings exposed to toxic concentrations of aluminum. Journal of Plant Cell Reports 26:2027-2038

Shaukat K, Affrasayab S, Hasnain S (2006) Growth responses of Triticum aestivum to plant growth promoting rhizobacteria used as a bio-fertilizer. Research Journal of Microbiology 1(4):30-338. https://doi.org/10.3923/jm.2006.330.338

Smith GH, Chaney K, Murray C, Le MS (2015) The effect of organo-mineral fertilizer applications on the yield of winter wheat, spring barley, forage maize and grass cut for silage. J. Environ. Protect. 6:103-109

Snedecor GW, Cochran WG (1980) Statistical Methods $7^{\text {th }}$ ed. The lowa State Univ., Press, Ames, IA

Stroganov BP (1962) Physiological basis of the salt tolerance of plants (under different types of soil salinization) Izd Akad. Nauk. USSR, Moscow

Taie HAA, Abdelhamid MT, Dawood MG, Nassar RMA (2013) Pre-sowing seed treatment with proline improves some physiological, biochemical and anatomical attributes of faba bean plants under sea water stress. Journal of Applied Sciences Research 9(4):2853-2867 https://pdfs.semanticscholar.org/ d3a4/fa5b550ad04279f025bb7cfbca31129dc083.pdf

Vartainan N, Hervochon P, Marcotte L, Larher F (1992) Proline accumulation during drought rhizogenesis in Brassica napus var. oleifera. Plant Physiol. 140: 623-628

Yan Z, Shirong G, Sheng S, Jin S, Takafumi T (2011) Effects of proline on photosynthesis, root reactive oxygen species (ROS) metabolism in two melon cultivars (Cucumis melo L.) under NaCl stress. Afri. J. Biote. 10:1838118390. https://doi.org/10.5897/AJB11.1073

Yang L, Zhao X, Zhu H, Paul M, Zu Y, Tang Z (2014) Exogenous trehalose largely alleviates ionic unbalance, ROS burst, and PCD occurrence induced by high salinity in Arabidopsis seedling. Front. Plant Sci., 29. https://doi.org/10.3389/ fpls.2014.00570

Yemm EW, Cocking EC (1955) The determination of amino acids with ninhydrin. Analyst 80:209-213

Yemm EW, Willis AJ (1954) The respiration of barley plants. IX. The metabolism of roots during assimilation of nitrogen. New Phytotol. 55:229-234

Zeid IM (2009) Trehalose as osmoprotectant for maize under salinity-induced stress. Research Journal of Agriculture and Biological Sciences 5:613-622 https://scholar.google.com.eg/scholar

\section{Publisher's Note}

Springer Nature remains neutral with regard to jurisdictional claims in published maps and institutional affiliations.

\section{Submit your manuscript to a SpringerOpen ${ }^{\circ}$ journal and benefit from:}

- Convenient online submission

- Rigorous peer review

- Open access: articles freely available online

High visibility within the field

- Retaining the copyright to your article

Submit your next manuscript at $\boldsymbol{\sim}$ springeropen.com 